\title{
EFFECT OF UV IRRADIATION ON VEGETABLE TANNED LEATHER
}

\section{INFLUENTA IRADIERII UV ASUPRA PIELII TĂBĂCITE VEGETAL}

\author{
Yanping GAO ${ }^{1,2}$, Shuang YANG ${ }^{1,2}$, Xiaoyun JIAN ${ }^{1,2}$, Lucreţia MIU ${ }^{3}$, Carmen GAIDĂU ${ }^{3}$, Wuyong CHEN ${ }^{1,2}$ \\ ${ }^{1}$ Key Laboratory of Leather Chemistry and Engineering of the Ministry of Education, Sichuan University, Chengdu, 610065, P. R. China \\ ${ }^{2}$ National Engineering Laboratory for Clean Technology of Leather Manufacture, Sichuan University, Chengdu 610065, P. R. China \\ ${ }^{3}$ INCDTP - Leather and Footwear Research Institute, 93 Ion Minulescu St, sector 3, 031215, Bucharest, Romania
}

EFFECT OF UV IRRADIATION ON VEGETABLE TANNED LEATHER

ABSTRACT. This article aims at studying the influence of UV irradiation on vegetable tanned leather. Vegetable tanned leather was treated in QUV chamber $\left(T=50^{\circ} \mathrm{C}\right.$, irradiance $=1.77 \mathrm{~W} / \mathrm{mm}^{2} \mathrm{~nm}, \ddot{\mathrm{e}}_{\mathrm{UVA}}=340 \mathrm{~nm}$ ) for $0,30,60,90,120$ and 150 hours. Then, these samples were evaluated by different analytical methods to get a whole picture of the leather during the irradiation. Micro hot table (MHT), differential scanning calorimetry (DSC) and thermogravimetry (TG) were used to evaluate the influences of UV irradiation on thermal behaviors. Damages to mechanical properties were also analyzed by a standard method. Fourier transform infrared spectroscopy (FT-IR) and optical microscopy were used to investigate the changes of structural and histological properties during aging process. With the extension of aging time, thermal stability was gradually reduced to lower values, including shrinkage temperature, thermal denaturation temperature, associated enthalpy and temperature for maximum decomposition rate. In addition, mechanical properties such as tensile strength, tear strength and elongation at break also gradually decreased. The FT-IR results showed that, during the aging process, amide I and amide II band of the tanned collagen gradually shifted to lower numbers, indicating an increasingly serious damage to the structure of the peptide chain, that corresponds to obvious fibril breakages which are also detected through optical microscopy.

KEY WORDS: UV irradiation, vegetable tanned leather, aging

\section{INFLUENTA IRADIERII UV ASUPRA PIELII TĂBĂCITE VEGETAL}

REZUMAT. Acest articol urmăreşte studiul influenţei iradierii UV asupra pielii tăbăcite vegetal. Pielea tăbăcită vegetal a fost tratată în camera QUV $\left(T=50^{\circ} \mathrm{C}\right.$, iradiere $=1,77 \mathrm{~W} / \mathrm{mm}^{2} \mathrm{~nm}, \ddot{e}_{\mathrm{uvA}}=340 \mathrm{~nm}$ ) timp de 0,30,60,90, 120 şi 150 de ore. Apoi, aceste probe au fost evaluate prin diferite metode analitice pentru a obţine o imagine de ansamblu a pielii în timpul iradierii. S-au utilizat microplaca încălzită (MHT), calorimetria cu scanare diferenţială (DSC) şi termogravimetria (TG) pentru a evalua influenţele iradierii UV asupra comportamentului termic. Deteriorarea proprietăţilor mecanice a fost, de asemenea, analizată utilizând o metodă standard. S-au utilizat spectroscopia în infraroşu cu transformată Fourier (FT-IR) şi microscopia optică pentru a investiga modificările proprietăţilor structurale şi histologice în timpul procesului de îmbătrânire. Cu prelungirea timpului de îmbătrânire, stabilitatea termică a fost redusă treptat la valori mai mici, inclusiv temperatura de contracţie, temperatura de denaturare termică, entalpia asociată şi temperatura vitezei maxime de descompunere. În plus, proprietăţi mecanice precum rezistenţa la rupere, rezistenţa la sfâşiere şi alungirea la rupere au scăzut treptat. Rezultatele FT-IR au arătat că, în timpul procesului de îmbătrânire, benzile amidă I şi amidă II ale colagenului tăbăcit s-au deplasat treptat la numere de undă mai mici, indicând o deteriorare mai serioasă a structurii lanţului peptidic, ce corespunde unor ruperi evidente ale fibrilelor, detectate, de asemenea, prin microscopie optică.

CUVINTE CHEIE: iradiere UV, piele tăbăcită vegetal, îmbătrânire

\section{L'EFFET DE L'IRRADIATION UV SUR LE CUIR TANNÉ VÉGÉTAL}

RÉSUMÉ. Cet article vise à étudier l'influence de l'irradiation UV sur le cuir tanné végétal. Le cuir tanné végétal est traité dans la chambre $Q U V\left(T=50^{\circ} \mathrm{C}\right.$, irradiance $=$ $1,77 \mathrm{~W} / \mathrm{mm}^{2} \mathrm{~nm}, \ddot{e}_{\text {UVA }}=340 \mathrm{~nm}$ ) pendant $0,30,60,90,120$ et 150 heures. Ensuite, ces échantillons ont été évalués par différentes méthodes analytiques pour obtenir une vue d'ensemble du cuir au cours de l'irradiation. On a utilisé la micro plaque chauffante (MHT), la calorimétrie différentielle à balayage (DSC) et la thermogravimétrie (TG) pour évaluer les influences de l'irradiation UV sur le comportement thermique. La détérioration causée aux propriétés mécaniques a également été analysée en employant une méthode standard. La spectroscopie infrarouge à transformée de Fourier (FT-IR) et la microscopie optique ont été utilisées pour étudier les changements de propriétés structurelles et histologiques au cours du processus de vieillissement. Avec l'extension du temps de vieillissement, la stabilité thermique a été progressivement réduite à des valeurs inférieures, y compris la température de rétraction, la température de dénaturation thermique, l'enthalpie associée et la température pour le taux maximal de décomposition. En outre, les propriétés mécaniques telles que la résistance à la traction, résistance à la déchirure et l'allongement à la rupture ont été également diminués progressivement. Les résultats FT-IR ont montré que, au cours du processus de vieillissement, les bandes amide I et amide II de collagène tanné ont été progressivement déplacées vers les numéros inférieurs, ce qui indique une détérioration de plus en plus grave pour la structure de la chaîne peptidique, qui correspond à des ruptures évidentes de fibrilles, détectées aussi par la microscopie optique.

MOTS CLÉS: irradiation UV, cuir tanné végétal, vieillissement 


\section{INTRODUCTION}

Vegetable tanned leather has been used in Europe and Asia throughout the ages starting from the Prehistoric Period up until the present time. Therefore, a large proportion of collagen-based cultural relics was made of vegetable tanned leather, such as ancient helmet, armor, belt, shoes etc. [1] These relics constitute an extremely valuable heritage, susceptible to environmental influences: changes of temperature and relative humidity, excessive light and air pollution $[2,3]$. However, vegetable tanned leather heritage objects are often exposed to the solar irradiation environment so that UV will lead to the aging and damage of vegetable tanned leather.

In previous papers, the effect of temperature, relative humidity and UV irradiation on chrome-tanned leather and wet-white leather have been studied [4,5]. It has been already demonstrated that UV irradiation may cause breakages in any positions of the peptides [6] and may change the viscosity and the optical rotation of collagen solution [7]. However, the studies of synthetic research techniques on the effect of UV irradiation on vegetable tanned leather are still rarely reported.

In this research, the GT-QUV/SE QUV chamber (GOTECH, China) was used to simulate the effect of UV irradiation on vegetable tanned leather. Vegetable tanned leather was treated in QUV chamber $\left(T=50^{\circ} \mathrm{C}\right.$, irradiance $=1.77 \mathrm{~W} / \mathrm{mm}^{2} \mathrm{~nm}$, $\lambda_{\mathrm{UvA}}=340 \mathrm{~nm}$ ) for $0,30,60,90,120$ and 150 hours. Some analytical techniques were used to evaluate the changes of leather during the aging process: DSC, TG and MHT were used to evaluate the variation of their thermal behaviors; tensile strength, tear strength and elongation at break were analyzed to show the damages of mechanical properties; FT-IR and optical microscopy were used to investigate the changes of structural and histological properties [8-10].

This study aims at providing some valuable references for storage of vegetable tanned leather and its cultural relics. Moreover, it may form the basis for improving the methods of leather aging.

\section{INTRODUCERE}

Pielea tăbăcită vegetal a fost folosită în Europa şi Asia de-a lungul timpului începând cu perioada preistorică şi până în prezent. Prin urmare, o mare parte din relicvele culturale pe bază de colagen, cum ar fi căşti, armuri, curele, încălţăminte etc., au fost făcute din piele tăbăcită vegetal [1]. Aceste relicve constituie un patrimoniu extrem de valoros şi sunt sensibile la influenţele mediului: schimbări de temperatură şi umiditate relativă, lumină excesivă şi poluarea aerului $[2,3]$. Cu toate acestea, patrimoniul din piele tăbăcită vegetal este adesea expus radiaţiei solare, astfel radiaţiile UV duc la îmbătrânirea şi deteriorarea pielii tăbăcite vegetal.

În articolele anterioare $s$-a studiat efectul temperaturii, umidităţii relative şi iradierii UV asupra pielii tăbăcite în crom şi pielii wet-white $[4,5]$. S-a demonstrat deja că iradierea UV poate provoca rupturi în orice poziţii ale peptidelor [6] şi poate modifica viscozitatea şi rotaţia optică a soluţiei de colagen [7]. Cu toate acestea, studiul tehnicilor de cercetare de sinteză cu privire la efectul iradierii UV asupra pielii tăbăcite vegetal sunt încă foarte rar raportate.

În acest studiu de cercetare s-a utilizat camera QUV GT-QUV/SE (GOTECH, China) pentru a simula efectul iradierii UV asupra pielii tăbăcite vegetal. Pielea tăbăcită vegetal a fost tratată în camera QUV (T $=50^{\circ} \mathrm{C}$, iradiere $=1.77 \mathrm{~W} / \mathrm{mm}^{2} \mathrm{~nm}, \lambda_{\mathrm{uvA}}=340 \mathrm{~nm}$ ) timp de $0,30,60,90,120$ şi 150 ore. S-au utilizat câteva tehnici analitice pentru a evalua modificările pielii în timpul procesului de îmbătrânire: s-au efectuat analizele DSC, TG şi MHT pentru a evalua variaţia comportamentului termic; rezistenţa la rupere, rezistenţa la sfâşiere şi alungirea la rupere au fost analizate pentru a evidenţia deteriorarea proprietăţilor mecanice; analiza FT-IR şi microscopia optică au fost folosite pentru a investiga modificările proprietăţilor structurale şi histologice [8-10].

Acest studiu îşi propune să ofere câteva referinţe valoroase pentru depozitarea pieilor tăbăcite vegetal şi a relicvelor culturale. Mai mult decât atât, poate constitui o bază pentru îmbunătăţirea metodelor de îmbătrânire a pielii. 


\section{EXPERIMENTAL}

\section{Materials}

Goat leather was prepared by purely vegetable tanning mimosa (commercial tannin, min. 60\% pure tannin) in drum. $20 \%$ vegetable tanning mimosa was used for 72 hours in the tanning process. Besides, $5 \%$ vegetable tanning mimosa and $8 \%$ natural type oil were used in the re-tanning process. Chemicals used for analysis were all research grade.

\section{Sampling}

In order to minimize the area differences from samples and increase the data reliability from tests, six large adjacent leather pieces $(10 \mathrm{~cm} \times 7 \mathrm{~cm})$ were cut along the back bone and used for mechanical properties tests. Another six small adjacent pieces ( 3 $\mathrm{cm} \times 2 \mathrm{~cm}$ ) were also cut along the back bone and used for structural, histological and thermal behavior analysis.

\section{Leather Aging Process}

The vegetable tanned leather samples were treated in the QUV chamber $\left(T=50^{\circ} \mathrm{C}\right.$, irradiance $=$ $1.20 \mathrm{~W} / \mathrm{m}^{2} \mathrm{~nm}, \lambda_{\mathrm{uvA}}=340 \mathrm{~m}$ ) for $0,30,60,90,120$ and 150 hours. Treated samples were collected and kept in glass desiccators for 48 hours, then the samples were placed in a $65 \% \mathrm{RH}$ desiccator one week for equilibrium.

\section{Analytical Methodology}

\section{MHT Analysis}

MHT measurements were performed with an easyto-use equipment composed of a stereo microscope (SBM-20TF China) and a hot table A WT2000 (China) equipped with a temperature processor and a homemade software for temperature regulation and data collection. Magnification used was $\times 40$.

A sample (1-2 mg) of fibers from the corium part of the samples was divided into triplicates. Each subsample was washed with distilled water for $10 \mathrm{~min}$, placed on a concave microscope slide and covered with distilled water and a microscope slip, with the prerequisite that more than two fibers should be

\section{PARTEA EXPERIMENTALĂ}

\section{Materiale}

Pielea de capră a fost preparată printr-un procedeu de tăbăcire pur vegetală cu mimoză (tanin comercial, min. $60 \%$ tanin pur). În procesul de tăbăcire s-a utilizat $20 \%$ tanant vegetal mimoză timp de 72 de ore. În plus, în procesul de retăbăcire s-au utilizat $5 \%$ tanant vegetal mimoză şi $8 \%$ ulei natural. Toate produsele chimice utilizate pentru teste au fost de calitate analitică.

\section{Prelevarea probelor}

Pentru a minimiza diferenţele de suprafaţă ale probelor şi pentru a creşte fiabilitatea datelor rezultate în urma testelor, s-au tăiat şase bucăţi mari adiacente de piele $(10 \mathrm{~cm} \times 7 \mathrm{~cm})$ de-a lungul şirei spinării şi s-au utilizat la încercări mecanice. S-au tăiat, de asemenea, încă şase bucăţi mici adiacente $(3 \mathrm{~cm} \times 2 \mathrm{~cm})$ şirei spinării şi s-au utilizat la analizele structurale, histologice şi termice.

\section{Procesul de îmbătrânire a pielii}

Probele de piele tăbăcită vegetal au fost tratate în camera QUV $\left(T=50^{\circ} \mathrm{C}\right.$, iradiere $=1,20 \mathrm{~W} / \mathrm{m}^{2} \mathrm{~nm}, \lambda_{\mathrm{UvA}}=$ $340 \mathrm{~m}$ ) timp de $0,30,60,90,120$ şi 150 de ore. Probele tratate au fost colectate şi păstrate în desicatoare de sticlă timp de 48 ore, apoi probele au fost plasate întrun desicator cu 65\% umiditate relativă timp de o săptămână pentru a ajunge la echilibru.

\section{Metodologie analitică}

\section{Analiza MHT}

Măsurătorile $\mathrm{MHT}$ au fost efectuate cu un echipament uşor de utilizat compus dintr-un stereomicroscop (SBM20TF China) şi o microplacă încălzită A WT2000 (China) cuplată cu un procesor de temperatură şi un software propriu pentru reglarea temperaturii şi colectarea datelor. Mărirea utilizată a fost de 40x.

Un eşantion (1-2 mg) de fibre din partea cu dermă a probelor a fost împărţit în trei. Fiecare subeşantion a fost spălat cu apă distilată timp de 10 min, plasat pe lama concavă de microscop şi acoperit cu apă distilată şi o lamelă de acoperire, putându-se observa cu ochiul liber mai mult de două fibre. Lama a 
observed in the sight. The slide was placed on the hot table and heated at a rate of $2^{\circ} \mathrm{C} \mathrm{min}{ }^{-1}$. $T_{\mathrm{s}}$ was recorded when more than two fibers were shrunk simultaneously and continuously. The final results were the average of three tests [11].

\section{DSC Analysis}

DSC measurements on leather samples were performed in the temperature range from 20 to $250^{\circ} \mathrm{C}$, at $10^{\circ} \mathrm{C} \mathrm{min}^{-1}$ heating rate in dry nitrogen flow $(20 \mathrm{ml}$ $\mathrm{min}^{-1}$ ) in sealed aluminium crucibles. Samples were analyzed in a dry condition after a few days' storage in a controlled environment (approximately $20^{\circ} \mathrm{C}$ and $65 \%$ $\mathrm{RH})$. Measurements were made with a NETZSCH DSC PC200 calorimeter (Germany).

\section{TG Analysis}

TG and DTG were simultaneously recorded with a NETZSCH TG 209 F1 thermogravimetric analyzer (Germany) from 40 to $800^{\circ} \mathrm{C}$, at $10^{\circ} \mathrm{C} \mathrm{min}^{-1}$ heating rate. Measurements were made in dry nitrogen flow $\left(20 \mathrm{ml} \mathrm{min}^{-1}\right)$ using $\mathrm{Al}_{2} \mathrm{O}_{3}$ crucibles. Samples were analyzed in a dry condition after a few days' storage in a controlled environment (approximately $20^{\circ} \mathrm{C}$ and $65 \% \mathrm{RH}$ ). The sample masses were 3 to $5 \mathrm{mg}$.

\section{Mechanical Properties}

Prior to the analysis of mechanical properties, the leather samples were sampled and conditioned according to the standard method [12, 13]. Tensile strength, tear strength and elongation at break of the samples were measured using an Al-7000S universal testing machine (Gotech China) following the standard method $[14,15]$.

\section{Optical Microscope Analysis}

The samples were sliced into $12 \mu \mathrm{m}$ pieces by freezing microtome (CM1950, Leica, German). After hematoxylin and eosin staining, the cross sections were observed by an optical microscope (SZX12 Olympus Optical Co., Ltd., Japan) at 40 times magnification to observe the changes of collagen fibres. fost plasată pe microplacă şi s-a încălzit cu o viteză de $2^{\circ} \mathrm{C} \mathrm{min}^{-1}$. S-a înregistrat $T_{\mathrm{s}}$ atunci când s-au contractat mai mult de două fibre simultan şi continuu. Rezultatele finale au reprezentat media a trei încercări [11].

\section{Analiza DSC}

Măsurătorile DSC s-au efectuat pe probele de piele în intervalul de temperatură $20-250^{\circ} \mathrm{C}$, la viteza de încălzire de $10^{\circ} \mathrm{C} \mathrm{min}^{-1}$ în curent de azot anhidru $(20 \mathrm{ml}$ $\min ^{-1}$ ) în creuzete de aluminiu sigilate. Probele au fost analizate în stare uscată, după o depozitare de câteva zile într-un mediu controlat (aproximativ $20^{\circ} \mathrm{C}$ şi $65 \%$ $\mathrm{RH})$. Măsurătorile au fost efectuate cu un calorimetru NETZSCH DSC PC200 (Germania).

\section{Analiza TG}

Valorile TG şi DTG au fost înregistrate simultan cu un analizor termogravimetric NETZSCH TG 209 F1 (Germania) în intervalul $4-80^{\circ} \mathrm{C}$, la viteza de încălzire de $10^{\circ} \mathrm{C} \mathrm{min}^{-1}$. Măsurătorile au fost efectuate în curent de azot anhidru $\left(20 \mathrm{ml} \mathrm{min}^{-1}\right)$, folosind creuzete $\operatorname{din} \mathrm{Al}_{2} \mathrm{O}_{3}$. Probele au fost analizate în stare uscată, după o depozitare de câteva zile într-un mediu controlat (aproximativ $20^{\circ} \mathrm{C}$ şi $65 \% \mathrm{RH}$ ). Masele probelor au fost de la 3 până la $5 \mathrm{mg}$.

\section{Proprietăţi mecanice}

Înainte de analiza proprietăţilor mecanice, probele de piele au fost eşantionate şi condiţionate utilizând metoda standard [12, 13]. Rezistenţa la rupere, rezistenţa la sfâşiere şi alungirea la rupere ale probelor au fost măsurate utilizând o maşină de testare universală Al-7000S (Gotech China) urmând metoda standard $[14,15]$.

\section{Analiza prin microscopie optică}

Probele au fost tăiate în bucăţi de $12 \mu \mathrm{m}$ utilizând microtomul de congelare (CM1950, Leica, Germania). După coloraţia cu hematoxilină şi eozină, secţiunile au fost observate la un microscop optic (SZX12 Olympus Optical Co, Ltd., Japonia), la mărire de 40 de ori pentru a observa modificările fibrelor de colagen. 


\section{FT-IR Analysis}

FTIR spectra in the $4000-400 \mathrm{~cm}^{-1}$ were recorded with a Nicolet 10 FT-IR spectrophotometer (American Thermo Scientific Corporation) equipped with a DLATGS detector and a $\mathrm{KBr}$ beam splitter. Samples were prepared by grinding about $1 \mathrm{mg}$ leather with $100 \mathrm{mg}$ $\mathrm{KBr}$ and pressing the mixture into very thin disks and were scanned for 32 times. The maximum resolution of measurements was $1 \mathrm{~cm}^{-1}$ [16].
Analiza FT-IR

Spectrele FTIR în regiunea $4000-400 \mathrm{~cm}^{-1}$ au fost înregistrate cu un spectrofotometru Nicolet 10 FT-IR (American Thermo Scientific Corporation) echipat $\mathrm{Cu}$ un detector DLATGS şi un separator de fascicule $\mathrm{KBr}$. Probele au fost preparate prin măcinarea a aproximativ $1 \mathrm{mg}$ de piele cu $100 \mathrm{mg} \mathrm{KBr}$ şi presarea amestecului în discuri foarte subţiri, care au fost scanate de 32 de ori. Rezoluţia maximă a măsurătorilor a fost de $1 \mathrm{~cm}^{-1}[16]$.

\section{RESULTS AND DISCUSSIONS}

\section{REZULTATE ŞI DISCUTII}

\section{Shrinkage Temperature}

\section{Temperatura de contracţie}

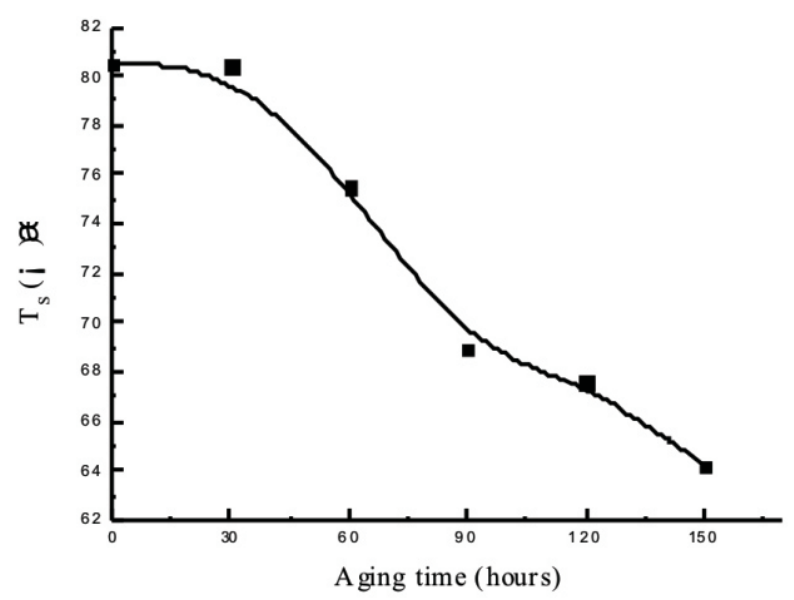

Figure 1. Shrinkage temperature of aged leather

Figura 1. Temperatura de contracţie a pielii îmbătrânite

Figure 1 shows the $T_{\mathrm{s}}$ of vegetable tanned leather as a function of aging days. The $T_{s}$ firstly decreases slowly after aging $30 \mathrm{~h}$, then drops sharply from 30 to $90 \mathrm{~h}$, finally falls relatively smoothly from 90 to $150 \mathrm{~h}$. The $T_{\mathrm{s}}$ of the sample is $80.5^{\circ} \mathrm{C}$ in the beginning and then reduces to $64.2^{\circ} \mathrm{C}$ after $150 \mathrm{~h}$, the $\Delta T$ is $16.3^{\circ} \mathrm{C}$. The shrinkage temperature of leather is a valuable indicator of the hydrothermal stability of collagen; the decreasing $T_{\mathrm{s}}$ represents the decreasing hydrothermal stability [11].
Figura 1 prezintă $T_{\mathrm{s}}$ a pielii tăbăcite vegetal pe parcursul perioadei de îmbătrânire. La început $T_{\mathrm{s}}$ scade încet după îmbătrânire timp de $30 \mathrm{~h}$, apoi scade brusc de la 30 la 90 de ore, şi în cele din urmă scade fără întreruperi de la 90 la $150 \mathrm{~h} . T_{\mathrm{s}}$ a probei este $80,5^{\circ} \mathrm{C}$ la început şi apoi scade la $64,2^{\circ} \mathrm{C}$ după $150 \mathrm{~h}, \Delta T$ este $16,3^{\circ} \mathrm{C}$. Temperatura de contracţie a pielii este un indicator valoros al stabilităţii hidrotermice a colagenului, $T_{\mathrm{s}}$ în scădere reprezentând scăderea stabilităţii hidrotermice [11]. 
Table 1: DSC and TG properties of aged leather Tabelul 1: Proprietăţile DSC şi TG ale pielii îmbătrânite

\begin{tabular}{|c|c|c|c|c|c}
\hline $\begin{array}{c}\text { Sample } \\
\text { Probă }\end{array}$ & $T_{\mathrm{d}} /{ }^{\circ} \mathrm{C}$ & $\Delta T_{\mathrm{d}}$ & $\Delta_{\mathrm{d}} H / \mathrm{J} / \mathrm{kg}$ & $T_{\max } /{ }^{\circ} \mathrm{C}$ & $\Delta T_{\max }$ \\
\hline UV-0 & 91.7 & 0 & 234.0 & 328.2 & 0 \\
\hline UV-30 & 90.2 & 1.5 & 164.2 & 325.9 & 2.3 \\
\hline UV-60 & 87.2 & 4.5 & 161.4 & 322.5 & 5.7 \\
\hline UV-90 & 83.0 & 8.7 & 140.5 & 317.7 & 10.5 \\
\hline UV-120 & 83.6 & 8.1 & 144.6 & 315.3 & 12.9 \\
\hline UV-150 & 80.5 & 11.2 & 136.9 & 311.9 & 16.3 \\
\hline
\end{tabular}

UV-0: control, UV-30: aging 30 hours, UV-60: aging 60 hours, UV-90: aging 90 hours, UV-120: aging 120 hours, UV-150: aging 150 hours UV-0: martor, UV-30: îmbătrânire 30 ore, UV-60: îmbătrânire 60 ore, UV-90: îmbătrânire 90 ore, UV-120: îmbătrânire 120 ore, UV-150: îmbătrânire 150 ore

DSC analysis of samples allows evaluating the denaturation temperature $\left(T_{d}\right)$ of the samples. $\Delta_{d} H$ is the peak area of the DSC curves and represents associated enthalpy during heating process. Both $T_{\mathrm{d}}$ and $\Delta_{\mathrm{d}} H$ (Table 1 ) decrease with the aging time, $T_{\mathrm{d}}$ reduces from 91.7 to $80.5^{\circ} \mathrm{C}$ and $\Delta_{\mathrm{d}} H$ drops from 234.0 to $136.9 \mathrm{~J} \mathrm{~kg}^{-1}$. According to previous DSC studies, lower $T_{\mathrm{d}}$ and $\Delta_{\mathrm{d}} H$ values reflect the decreased thermal stability of collagen caused by its progressive deterioration [17].

The temperature of the maximum speed of the process $\left(T_{\text {max }}\right)$ was determined by DTG curve. As shown in Table 1, the results of the $T_{\max }$ decrease from 328.2 to $311.9^{\circ} \mathrm{C}$ and $\Delta T_{\text {max }}$ is $16.3^{\circ} \mathrm{C}$ during the aging process. The modification of leather structure after UV irradiation can reduce the decomposition temperature, and consequently reduce the thermal stability of the leather [18].

\section{Mechanical Property}

Results of tensile strength, tear strength and elongation at break, during the aging time are shown in Figures 2, 3 and 4. Both tensile strength and tear strength firstly rise slowly from 0 to $60 \mathrm{~h}$, then drop sharply from 60 to $150 \mathrm{~h}$. The elongation at break reduces sharply between 0 to $60 \mathrm{~h}$ and falls slowly from 60 to $150 \mathrm{~h}$.
Analiza DSC a probelor permite evaluarea temperaturii de denaturare $\left(T_{\mathrm{d}}\right)$ a probelor. $\Delta_{\mathrm{d}} H$ este zona de vârf a curbelor DSC şi reprezintă entalpia asociată în timpul procesului de încălzire. Atât $T_{\mathrm{d}}$ cât şi $\Delta_{\mathrm{d}} H$ (Tabelul 1) scad odată cu timpul de îmbătrânire, $T_{\mathrm{d}}$ scade de la 91,7 la $80,5^{\circ} \mathrm{C}$, iar $\Delta_{\mathrm{d}} H$ scade de la 234,0 la $136,9 \mathrm{~J} \mathrm{~kg}^{-1}$. Conform studiilor DSC anterioare, valorile mai mici ale $T_{\mathrm{d}}$ şi $\Delta_{\mathrm{d}} H$ reflectă scăderea stabilităţii termice a colagenului, cauzată de o deteriorare progresivă a acestuia [17].

Temperatura vitezei maxime a procesului $\left(T_{\max }\right)$ a fost determinată prin curba DTG. Aşa cum se arată în Tabelul 1, valorile $T_{\text {max }}$ scad de la 328,2 la $311,9^{\circ} \mathrm{C}$, iar $\Delta T_{\max }$ este $16,3^{\circ} \mathrm{C}$ în timpul procesului de îmbătrânire. Modificarea structurii pielii după iradierea UV poate scădea temperatura de descompunere, reducând astfel stabilitatea termică a pielii [18].

\section{Proprietăţi mecanice}

Rezultatele încercărilor de rezistenţă la rupere, rezistenţă la sfâşiere şi alungire la rupere în timpul îmbătrânirii sunt prezentate în Figurile 2, 3 şi 4 . Atât rezistenţa la rupere, cât şi cea la tracţiune cresc iniţial încet de la 0 la 60 de ore, apoi scad brusc în intervalul 60-150 h. Alungirea la rupere scade brusc între 0 şi 60 de ore şi apoi încet în intervalul 60-150 h. 


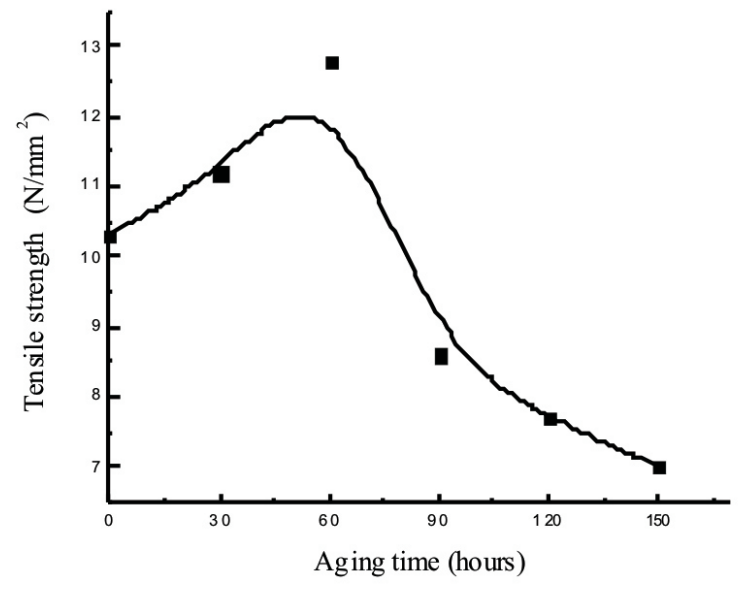

Figure 2. The tensile strength of aged leathers Figura 2. Rezistenţa la rupere a pielii îmbătrânite

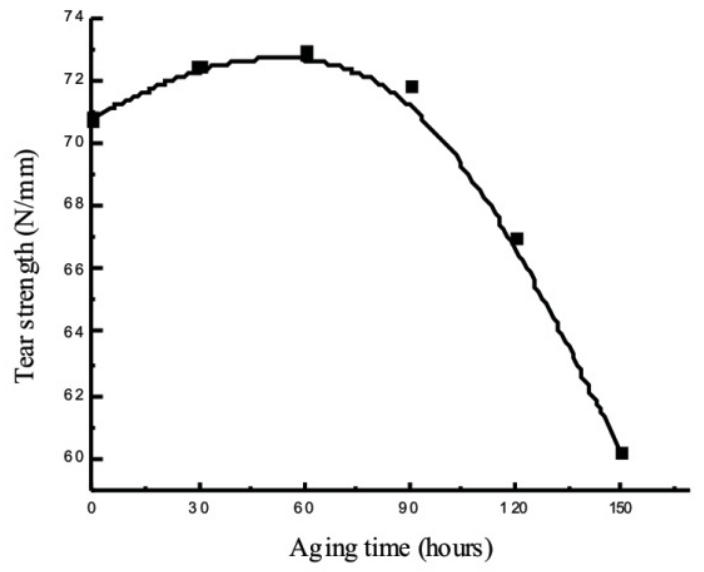

Figure 3. The tear strength of aged leathers Figura 3. Rezistenţa la sfâşiere a pielii îmbătrânite

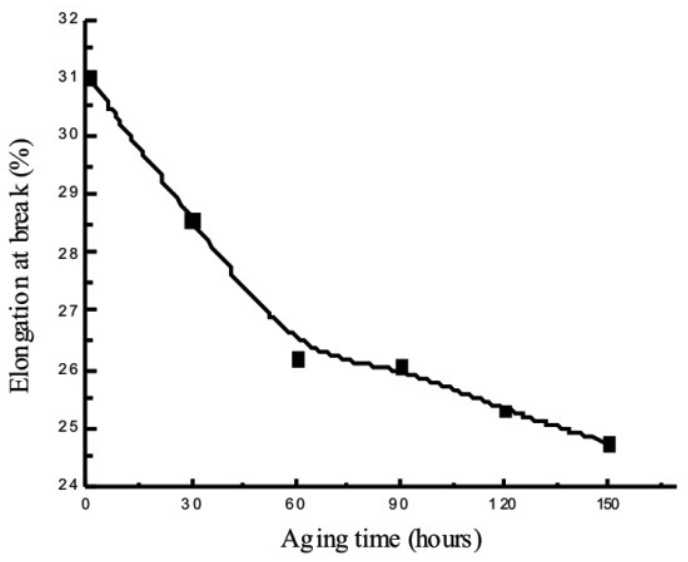

Figure 4. The elongation at break of aged leathers Figura 4. Alungirea la rupere a pielii îmbătrânite

The decreasing thermal stability and the loss of mechanical properties of samples may be referred to the reduction of combination between collagen fibres and vegetable tannin which leads to partly detanning of samples because of the effect of UV irradiation. Moreover, during the aging process, collagen peptide chains may be ruptured randomly and lead to the destruction of the collagen fibers and the decrease of cross-linking degree, therefore the thermal stability and mechanical properties of the leather were reduced.
Stabilitatea termică în scădere şi pierderea proprietăţilor mecanice ale probelor pot indica reducerea combinaţiei dintre fibrele de colagen şi taninul vegetal care duce la detăbăcirea parţială a probelor din cauza efectului iradierii UV. Mai mult decât atât, în timpul procesului de îmbătrânire, lanţurile peptidice ale colagenului se pot rupe la întâmplare şi pot conduce la distrugerea fibrelor de colagen şi scăderea gradului de reticulare, prin urmare se reduc stabilitatea termică şi proprietăţile mecanice ale pielii. 


\section{Morphology and Structure}

The decrease of thermal stability and mechanical properties of vegetable tanned leather may be explained by the changes of morphology and structure.

\section{Morfologie şi structură}

Scăderea stabilităţii termice şi a proprietăţilor mecanice ale pielii tăbăcite vegetal poate fi explicată prin modificările de morfologie şi structură.

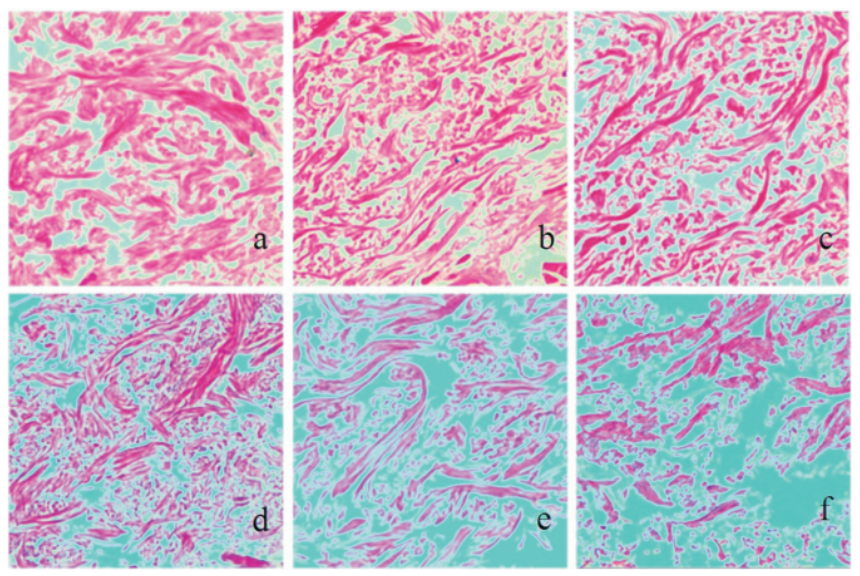

Figure 5. Optical micrographs of aged leather (at a magnification of 40x):

a) UV-0; b) UV-30; c) UV-60; d) UV-90; e) UV-120; f) UV-150

Figura 5. Micrografii optice ale pielii îmbătrânite (la mărire 40x):

a) UV-0; b) UV-30; c) UV-60; d) UV-90; e) UV-120; f) UV-150

Figure 5 shows the collagen fibers woven more and more loosely and the gaps among collagen fibres become bigger and bigger with the aging time (Figure $5 b, c, d$, e and f) compared with the matched samples (Figure 5a), indicating that the collagen fibers were greatly damaged with the impact of UV irradiation.

After the effect of UV irradiation, the structure of collagen fibres with peptide bonds had been severely changed and the changed structure of collagen could be evaluated with FT-IR.
Figura 5 arată fibrele de colagen întrețesute din ce în ce mai larg şi spaţiile dintre fibrele de colagen din ce în ce mai mari, pe parcursul îmbătrânirii (Figura 5b, c, d, e şi f), comparativ cu proba martor (Figura 5a), indicând faptul că fibrele de colagen s-au deteriorat foarte mult la impactul iradierii UV.

După efectul iradierii UV, structura fibrelor de colagen cu legăturile peptidice s-a schimbat drastic, structura modificată a colagenului putând fi evaluată prin FT-IR.

Table 2: The shift of Amide I and Amide II band of aged leather Tabelul 2: Deplasarea benzilor amidă I şi amidă II ale pielii îmbătrânite

\begin{tabular}{|c|c|c|c|c|}
\hline $\begin{array}{c}\text { Sample } \\
\text { Probă }\end{array}$ & $\begin{array}{c}\text { Amide I }\left(\mathrm{cm}^{-1}\right) \\
\text { Amidă I }\left(\mathrm{cm}^{-1}\right)\end{array}$ & $\begin{array}{c}\Delta \text { Amide I }\left(\mathrm{cm}^{-1}\right) \\
\Delta \text { Amidă I }\left(\mathrm{cm}^{-1}\right)\end{array}$ & $\begin{array}{c}\text { Amide II }\left(\mathrm{cm}^{-1}\right) \\
\text { Amidă II }\left(\mathrm{cm}^{-1}\right)\end{array}$ & $\begin{array}{c}\Delta \text { Amide II }\left(\mathrm{cm}^{-1}\right) \\
\Delta \text { Amidă II }\left(\mathrm{cm}^{-1}\right)\end{array}$ \\
\hline \hline UV-0 & 1661.99 & 0 & 1548.89 & 0 \\
\hline UV-30 & 1647.48 & 14.51 & 1541.99 & 6.9 \\
\hline UV-60 & 1654.34 & 7.65 & 1536.52 & 12.37 \\
\hline UV-90 & 1642.57 & 19.42 & 1525.43 & 23.46 \\
\hline UV-120 & 1637.38 & 24.61 & 1514.52 & 34.37 \\
\hline UV-150 & 1631.72 & 30.20 & 1459.48 & 89.41 \\
\hline
\end{tabular}


The Table 2 represents the changes of amide I band (1650-1665 $\mathrm{cm}^{-1}$ ) and amide II band (1530-1550 $\mathrm{cm}^{-1}$ ) during UV treatment, the frequencies of two bands are shifted to the range of lower values and the shift of amide II band is greater. The Amide I band moves from 1661.99 to $1631.72 \mathrm{~cm}^{-1}$ and $\Delta$ Amide I is $30.20 \mathrm{~cm}^{-1}$. The Amide II shifts from $1548.89 \mathrm{~cm}^{-1}$ to $1459.48 \mathrm{~cm}^{-1}$ and $\Delta$ Amide II is $89.41 \mathrm{~cm}^{-1}$. These results suggest that the role of UV irradiation destroys the ordered structure of tanned collagen peptides and the main changes have taken place in the group of $\mathrm{C}=\mathrm{O}$ and $\mathrm{N}-\mathrm{H}[19]$.

\section{CONCLUSION}

The vegetable tanned leather was aged by UV irradiation and with the aging time, the thermal stability dropped obviously; the tensile strength, tear strength and elongation of the aged leather also decreased; the collagen fibers were damaged and the gaps of fibers were enlarged; the Amide I and Amide II band in the tanned collagen were shifted to lower wave numbers. In conclusion, the UV has a significant effect on vegetable tanned leather, leading to damaged morphology and changed structure. In other words, UV has a great impact on the vegetable tanned leather historical relics and products.

\section{Acknowledgement}

The authors wish to thank Doctoral Scientific Fund Project of the Ministry of Education (Item No. 20130181130009) and the Ministry of Science and Technology of China for the project of Co-operation in Science and Technology between Romania and China (item No. 2009DFA42850).
Tabelul 2 prezintă modificările benzilor amidă I $\left(1650-1665 \mathrm{~cm}^{-1}\right)$ şi amidă II (1530-1550 cm $\left.\mathrm{cm}^{-1}\right)$ în timpul tratamentului UV; frecvenţele celor două benzi se deplasează în intervalul valorilor mai mici, iar deplasarea benzii amidă II este mai mare. Banda amidă I se deplasează de la 1661,99 la $1631,72 \mathrm{~cm}^{-1}$ şi $\Delta$ amida I este la $30,20 \mathrm{~cm}^{-1}$. Amida II trece de la $1548,89 \mathrm{~cm}^{-1}$ la $1459,48 \mathrm{~cm}^{-1}$, iar $\Delta$ amida II este la $89,41 \mathrm{~cm}^{-1}$. Aceste rezultate sugerează că iradierea UV distruge structura ordonată a peptidelor din colagen şi principalele modificări au apărut la grupările $\mathrm{C}=\mathrm{O}$ şi $\mathrm{N}-\mathrm{H}[19]$.

\section{CONCLUZII}

Pielea tăbăcită vegetal a fost îmbătrânită prin iradiere UV şi odată cu trecerea timpului, stabilitatea termică a scăzut în mod evident; rezistenţa la rupere, rezistenţa la sfâşiere şi alungirea la rupere ale pielii îmbătrânite au scăzut, de asemenea; fibrele de colagen s-au deteriorat şi spaţiile dintre fibre s-au extins; benzile amidă I şi amidă II din colagenul tăbăcit s-au deplasat spre numere de undă mai mici. În concluzie, UV are un efect semnificativ asupra pielii tăbăcite vegetal, ducând la deteriorarea morfologiei şi la modificarea structurii. $\mathrm{Cu}$ alte cuvinte, UV are un impact mare asupra relicvelor şi produselor din piele tăbăcită vegetal.

\section{Mulţumiri}

Autorii doresc să mulţumească Ministerului Educaţiei pentru sprijinul financiar acordat prin intermediul Proiectului de Finanţare a Cercetării Ştiinţifice în cadrul Doctoratelor (nr. 20130181130009) şi Ministerului Ştiinţei şi Tehnologiei din China pentru proiectul de cooperare în domeniul ştiinţei şi tehnologiei dintre România şi China (nr. 2009DFA42850).

\section{REFERENCES}

1. Falcao, L., Araujo, M.E.M., Tannins characterization in historic leathers by complementary analytical techniques ATRFTIR, UV-Vis, and chemical tests, J Cult Herit, 2013, 14, 6, 499-508.

2. Krupińska, B., Worobiec, A., Gatto Rotondo, G., Novakovi, V., Kontozova, V., Ro, C.U., Van Grieken, R., De Wael, K., Assessment of the air quality $\left(\mathrm{NO}_{2}, \mathrm{SO}_{2}, \mathrm{O}_{3}\right.$ and particulate matter) in the Plantin-Moretus Museum/Print Room in 
Antwerp, Belgium, in different seasons of the year, Microchem. J., 2012, 102, 49-53.

3. Isik, N.O., Karavana, H.A., Revista de Pielarie Incaltaminte (Leather and Footwear Journal), 2010, 10, 4, 25-32.

4. Bacardit, A., Jorba, M., Font Vallčs, J., Olle, L., Study of the effect of temperature, relative humidity and UV radiation on chrome-tanned leather ageing, J. Am. Leather Chem. As., 2012, 107, 6, 179-185.

5. Bacardit, A., Cobos, M., Font Vallčs, J., Jorge, J., Olle, L., Study of the effect of temperature, relative humidity and UV radiation on white-wet leather ageing, J. Am. Leather Chem. As., 2010, 105, 10, 334-341.

6. Miyata, T., Sohde, T., Rubin, A.L., Stenzil, K.H., Effect of ultraviolet irradiation on native and telopeptide-poor collagen, Biochem. Biophys. Acta, 1971, 229, 672-680.

7. Miles, C.A., Sionkowska, A., Hulin, S.L., Identification of an intermediate state in helix-coil degradation of collagen by ultraviolet radiation, J. Biol. Chem., 2000, 275, 42, 33014-33020.

8. Carsote, C., Miu, L., Petroviciu, I., Creanga, D.M., Giurginca, M., Vetter, W., Revista de Pielarie Incaltaminte (Leather and Footwear Journal), 2012, 12, 3, 183-192.

9. Gao, Y., Yang, S., Jian, X., J., Miu, L., Gaidau, C., Chen, W., Revista de Pielarie Incaltaminte (Leather and Footwear Journal), 2015, 15, 2, 107-116.

10. Miu, L, Badea, E., Budrugeac, P., Giurginca, M., Laurora, C., Carsote, C., Della Gatta, G., Revista de Pielarie Incaltaminte (Leather and Footwear Journal), 2008, 8, 1, 12-20.

11. Larsen, R., Vest, M., Nielsen, K., Determination of hydrothermal stability (Shrinkage temperature) of historical leather by the micro hot table technique, J. Soc. Leath. Tech. Ch., 1995, 77, 151-156.

12. IUP 2; Sampling. J. Soc. Leath. Tech. Ch., 2000, 84, 303-309.

13. IUP 3; Conditioning. J. Soc. Leath. Tech. Ch., 1998, 82, 199.

14. IUP 6; Measurement of tensile strength and percentage of elongation, J. Soc. Leath. Tech. Ch., 2000, 84, 317.

15. IUP 8; Measurement of tear load-double edge load, J. Soc. Leath. Tech. Ch., 2000, 84, 327.

16. Badea, E., Miu, L., Budrugeac, P., Giurginca, M., Masic, A., Badea, N., Della Gatta, G., Study of deterioration of historical parchments by various thermal analysis techniques complemented by SEM, FTIR, UV-VIS-NIR, and unilateral NMR investigations, J. Therm. Anal. Calorim., 2008, 91, 1, 17-27.

17. Budrugeac, P., Badea, E., Della Gatta, G., Miu, L., Comanescu, A., A DSC study of deterioration caused by environmental chemical pollutants to parchment, a collagen-based material, Thermochim. Acta, 2010, 500, 51-62.

18. Marcilla, A., García, A.N., León, M., Martinez, P., Banon, E., Study of the influence of NaOH treatment on the pyrolysis of different leather tanned using thermogravimetric analysis and Py/GC-MS system, J. Anal. Appl. Pyrol., 2011, 92, 194-201.

19. Petibois, C., Gouspillou, G., Wehbe, K., Delage, J.P., Déléris, G., Analysis of type I and IV collagens by FT-IR spectroscopy and imaging for a molecular investigation of skeletal muscle connective tissue, Anal. Bioanal. Chem., 2006, 386, 1961-1966.

Article received/Data primirii articolului: 21.05.2015

Accepted/Acceptat la data: 10.12.2015 